\title{
The compound 2-benzylthio-5,8-dimethoxynaphthalene-1,4-dione leads to apoptotic cell death by increasing the cellular reactive oxygen species levels in Ras-mutated liver cancer cells
}

\author{
GUI-NAN SHEN $^{1 *}$, JING LI $^{1 *}$, YING-HUA JIN $^{2 *}$, HU-NAN SUN ${ }^{1}$, YING-YING HAO ${ }^{1}$, MEI-HUA JIN ${ }^{1}$, REN LIU ${ }^{1}$, \\ WEI-LONG LI ${ }^{1}$, YONG-QING ZHANG ${ }^{1}$, JIA-BIN YU ${ }^{1}$, NAN-NAN YU ${ }^{1}$, WEI-DONG WANG ${ }^{1}$, \\ LI-YUN YU ${ }^{1}$, JI-SU KIM ${ }^{3}$, TAEHO KWON ${ }^{3}$ and YING-HAO HAN ${ }^{1}$ \\ ${ }^{1}$ College of Life Science and Biotechnology and ${ }^{2}$ Library and Information Center, Heilongjiang Bayi \\ Agricultural University, Daqing, Heilongiiang 163319, P.R. China; ${ }^{3}$ Primate Resources Center, \\ Korea Research Institute of Bioscience and Biotechnology, Jeongeup-si, Jeonbuk 56216, Republic of Korea
}

Received January 17, 2020; Accepted July 7, 2020

DOI: $10.3892 /$ etm.2020.9209

\begin{abstract}
The aim of the present study was to verify the pro-apoptotic anticancer potential of several 5,8-dimethoxy-1,4-phthoquinone (DMNQ) derivatives in Ras-mediated tumorigenesis. MTT assays were used to detect cellular viability and flow cytometry was performed to assess intracellular reactive oxygen species (ROS) levels and apoptosis. The expression levels of proteins were detected via western blotting. Among the 12 newly synthesized DMNQ derivatives, 2-benzylthio5,8-dimethoxynaphthalene-1,4-dione (BZNQ; component \#1) significantly reduced cell viability both in mouse NIH3T3 embryonic fibroblasts cells (NC) and H-Ras ${ }^{\mathrm{G} 12 \mathrm{~V}}$ transfected mouse NIH3T3 embryonic fibroblasts cells (NR). Moreover, BZNQ resulted in increased cytotoxic sensitivity in Ras-mutant transfected cells. Furthermore, the reactive oxygen species (ROS) levels in H-Ras ${ }^{\mathrm{G} 12 \mathrm{~V}}$ transfected HepG2 liver cancer cells (HR) were significantly higher compared with the levels in HepG2 liver cancer cells (HC) following BZNQ treatment, which further resulted in increased cellular apoptosis. Eliminating
\end{abstract}

Correspondence to: Dr Taeho Kwon, Primate Resources Center, Korea Research Institute of Bioscience and Biotechnology, 351-33 Neongme-gil, Ibam-myeon, Jeongeup-si, Jeonbuk 56216, Republic of Korea

E-mail: kwon@kribb.re.kr

Dr Ying-Hao Han, College of Life Science and Biotechnology, Heilongjiang Bayi Agricultural University, 5 Xinfeng-avenue, Daqing, Heilongjiang 163319, P.R. China

E-mail: hyhbynd@163.com

*Contributed equally

Abbreviations: DMNQ, 5,8-dimethoxy-1,4-phthoquinone; ROS, reactive oxygen species; NAC, N-acetyl-L-cysteine; BZNQ, 2-benzylthio-5,8-dimethoxynaphthalene-1,4-dione

Key words: naphtoquinone, apoptosis, Ras, reactive oxygen species, 5,8-dimethoxy-1,4-phthoquinone cellular ROS using an ROS scavenger N-acetyl-L-cysteine markedly reversed BZNQ-induced cellular ROS accumulation and cell apoptosis in HC and HR cells. Western blotting results revealed that BZNQ significantly downregulated H-Ras protein expression and inhibited the Ras-mediated downstream signaling pathways such as protein kinase B, extracellular signal-related kinase and glycogen synthase kinase phosphorylation and $\beta$-catenin protein expression. These results indicated that the novel DMNQ derivative BZNQ may be a therapeutic drug for Ras-mediated liver tumorigenesis. The results of the current study suggest that BZNQ exerts its effect by downregulating H-Ras protein expression and Ras-mediated signaling pathways.

\section{Introduction}

The incidence of $R A S$ gene mutations in all known human cancers is $\sim 30 \%$ worldwide over the last 30 years (1). Although the mutation in the $R A S$ gene is not the direct cause of all cancers, it has been reported to promote tumor occurrence, development and metastasis (2). Ras protein GTPase activity was reported to serve a key role in the process of human carcinogenesis more than 30 years ago $(3,4)$. Furthermore, the $R A S$ gene has been demonstrated to be one of the most mutated oncogenes in humans and to promote further development of tumors (5). A previous study demonstrated that mutant $R A S$ gene stimulated cell proliferation and inhibited cell apoptosis, thereby promoting tumor occurrence, survival, migration, diffusion and angiogenesis (6). Therefore, Ras protein is used as a target for drug treatment; however, due to the complexity of the Ras signaling pathway and its unique structure, drugs cannot actively target Ras to bind directly of the protein (7).

In recent years, naphthoquinone derivatives have become a focus of interest due to their ability to effectively cause death in cancer cells, including those in lung cancer (8), breast cancer (9) and colon cancer (10). However, naphthoquinone reportedly exerts low cytotoxic effects on healthy cells compared with currently used, existing clinical drugs, including 5-fluorouracil, cisplatin and sorafenib (11). Naphtoquinone derivatives are 
primarily constructed through multiple additions and substitutions with shikonin as the primary substrate to obtain a variety of derivatives with different structures (12). The 5,8-dimethoxy-1,4-naphthoquinone (DMNQ) compound is commonly used to synthesize naphthoquinone derivatives. It has been reported that DMNQ derivatives can inhibit tumor activity in lung (13) and breast cancers (14). Since each derivative has different substituents, the resulting functions of each derivative are subsequently different (15). According to previous research, naphthoquinone derivatives primarily aim to target two different physiological processes to cause cell death: i) To induce cytotoxicity by increasing intracellular reactive oxygen species (ROS) levels, which causes damage to mitochondrial function in cells, endoplasmic reticulum stress and autophagy that lead to cell death (16); and ii) to directly cause cytotoxicity, DNA strand breakage and cell cycle arrest (17). In hepatocarcinoma cells, naphthoquinone derivatives were reported to suppress hepatocarcinoma liver cancer cell proliferation, inhibit angiogenesis and promote cellular apoptosis by inhibiting DNA synthesis $(18,19)$. Research into drugs targeting Ras has made progress (20). Certain research demonstrated that 2,3-dichloro-1,4-naphthoquinone inhibited the growth of N-Ras-mutant melanoma (21), while 2-(2',4'-dihydroxyphenyl)-8-hydroxy-1,4-naphthoquinone and 5-hydroxy-2-(2,4-dihydroxyphenyl)naphthalene-1,4-dione inhibited Apc/K-Ras-mutant mouse organoid differentiation capacity (22). These results indicate that naphthoquinone derivatives have a certain inhibitory effect on the proliferation and differentiation of cancer cells and Ras signaling.

Therefore, the present study used shikonin as the main backbone to which to add different substituents and to design a variety of naphtoquinone derivatives, to select and investigate the anticancer mechanism of drugs with lower cytotoxicity for normal cells and higher lethality for cancer cells. Furthermore, the present study aimed to establish novel structural modification sites, while retaining the structure of derivatives for targeting Ras signaling to maximize the anticancer effect and reduce cytotoxicity, which may have practical significance for the development of targeted drugs.

\section{Materials and methods}

Materials. Solvents of reagent grade and were used without further purification. ${ }^{1} \mathrm{H}$ NMR and ${ }^{13} \mathrm{C}$ NMR spectra were recorded using a JNM-AL $400(400 \mathrm{MHz})$ spectrometer, Chemical shift ppm $(\delta)$ were relative to internal standard tetramethylsilane. MS spectra were recorded with an AB SCIEX API 2000 LC/MS/MS (Applied Biosystems; Thermo Fisher Scientific, Inc.) and LCMS-IT-TOF (Shimadzu Corporation).

Synthesis of 5,8-dimethoxy-1,4-naphthoquinone (DMNQ) derivatives. Synthetic schemes for 12 DMNQ derivatives are summarized in Fig. 1.

Synthesis of 5,8-dihydoroxy-1,4-naphthoquinone. 1,4-Dimethoxybenzene (1 equivalent) (Sigma-Aldrich; Merck KGaA) and maleic anhydride (2 equivalent) (Sigma-Aldrich; Merck KGaA) were added to the molten material of $\mathrm{NaCl}$ (4 equivalent) (Tianjin Damao Chemical Reagent Co., Ltd.) and aluminum chloride (8 equivalent, $171-177^{\circ} \mathrm{C}$ ) (Tianjin Damao Chemical Reagent Co., Ltd.) to give the condensed mixture. The derivatives were then treated with 1.2 liters $\mathrm{H}_{2} \mathrm{O}$ and $120 \mathrm{ml} \mathrm{95 \%} \mathrm{HCl}$ (Tianjin Damao Chemical Reagent Co., Ltd.) to generate DMNQ (Fig. 1A-a).

Synthesis of 1,4,5,8-tetramethoxynaphthalene. A solution of $25 \mathrm{ml}$ methyl $p$-toluene sulfonate (Sigma-Aldrich; Merck KGaA), 10.6 g sodium dithionite (Tianjin Damao Chemical Reagent Co., Ltd.) in $40 \mathrm{ml} \mathrm{70 \%} \mathrm{NaOH}$ (Tianjin Damao Chemical Reagent Co., Ltd.) was added to a solution of $20.1 \mathrm{~g}$ (Fig. 1A-a) in $200 \mathrm{ml}$ tetrahydrofuran (Tianjin Damao Chemical Reagent Co., Ltd.), $220 \mathrm{ml} \mathrm{H}_{2} \mathrm{O}$ and $2.2 \mathrm{~g}$ tetrabutylammonium bromide (Sigma-Aldrich; Merck KGaA). The mixture was stirred at $25^{\circ} \mathrm{C}$ for $20 \mathrm{~h}$ until a red precipitate formed, which was filtered and recrystallized in petroleum ether (Tianjin Damao Chemical Reagent Co., Ltd.) $\left(90-120^{\circ} \mathrm{C}\right)$ to produce an intermediate 1,4,5,8-tetramethoxynaphthalene product (Fig. 1A-b).

Synthesis of DMNQ. An amount $5.5 \mathrm{~g}$ cerium (IV) diammonium nitrate (Tianjin Damao Chemical Reagent Co., Ltd.) was dissolved in $250 \mathrm{ml} \mathrm{H}_{2} \mathrm{O}$ and added drop-wise to a solution

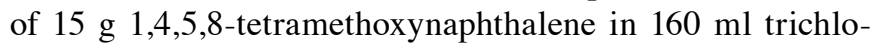
romethane (Tianjin Damao Chemical Reagent Co., Ltd.) and $480 \mathrm{ml}$ acetonitrile (Tianjin Damao Chemical Reagent Co., Ltd.). This mixture was stirred at $25^{\circ} \mathrm{C}$ for $1.5 \mathrm{~h}$. The key compound DMNQ (Fig. 1A-c) was obtained by this oxidation reaction.

Synthesis of the DMNQ derivatives \#1. DMNQ solution $(300 \mathrm{mg} ; 1.37 \mathrm{mmol})$ in $40 \mathrm{ml}$ ethyl alcohol $(\mathrm{EtOH}$, Tianjin Damao Chemical Reagent Co., Ltd.) was added to benzyl mercaptan (204.9 mg; 1.65 mmol; Sigma-Aldrich; Merck KGaA; Fig. 1B-\#1) for derivative \#1, 2-phenylethyl mercaptan (228.1 mg; 1.65 mmol; Sigma-Aldrich; Merck KGaA; Fig. 1B-\#2) for derivative \#2, 3,4-dimethoxybenzenethiol (280.9 mg; 1.65 mmol; Sigma-Aldrich; Merck KGaA; Fig. 1B-\#3) for derivative \#3, 4-tert-butylphenylmethanethiol (297.5 mg; $1.65 \mathrm{mmol}$; Sigma-Aldrich; Merck KGaA; Fig. 1B-\#4) for derivative \#4, phenyl amine (148.7 mg; $1.65 \mathrm{mmol}$; Sigma-Aldrich; Merck KGaA; Fig. 1B-\#5) for derivative \#5, cyclo-propyl amine (84.0 mg; 1.65 mmol; Sigma-Aldrich; Merck KGaA; Fig. 1B-\#6) for derivative \#6, 2-methylpropan-1-amine (120.6 mg; 1.65 mmol; Sigma-Aldrich; Merck KGaA; Fig. 1B-\#7) for derivative \#7, 2-mercaptoethanol (128.9 mg; $1.65 \mathrm{mmol}$; Sigma-Aldrich; Merck KGaA; Fig. 1B-\#9) for derivative \#9, 6-mercaptohexan-1-ol (221.5 mg; 1.65 mmol; Sigma-Aldrich; Merck KGaA; Fig. 1B-\#10) for derivative \#10, 4-mercaptophenol (208.2 mg; 1.65 mmol; Sigma-Aldrich; Merck KGaA; Fig. 1B-\#11) for derivative \#11 and 10-mercaptodecanoic acid (337.1 mg; 1.65 mmol; Sigma-Aldrich; Merck KGaA; Fig. 1B-\#12) for derivative \#12. The reaction mixture was stirred at room temperature for $4.5 \mathrm{~h}$. The resulting solution was added dropwise to a solution of 0.24 mmol sodium dichromate (Tianjin Damao Chemical Reagent Co., Ltd.) and 0.77 mmol sulfuric acid (Tianjin Damao Chemical Reagent Co., Ltd.) in $10 \mathrm{ml} \mathrm{H}_{2} \mathrm{O}$. The resulting mixture was stirred for a few minutes, extracted with methylene chloride $\left(\mathrm{CH}_{2} \mathrm{Cl}_{2}\right.$; Tianjin Damao Chemical Reagent Co., Ltd.), concentrated and recrystallized in EtOH to generate the target compound \#1 (Fig. 1B-\#1). 
A

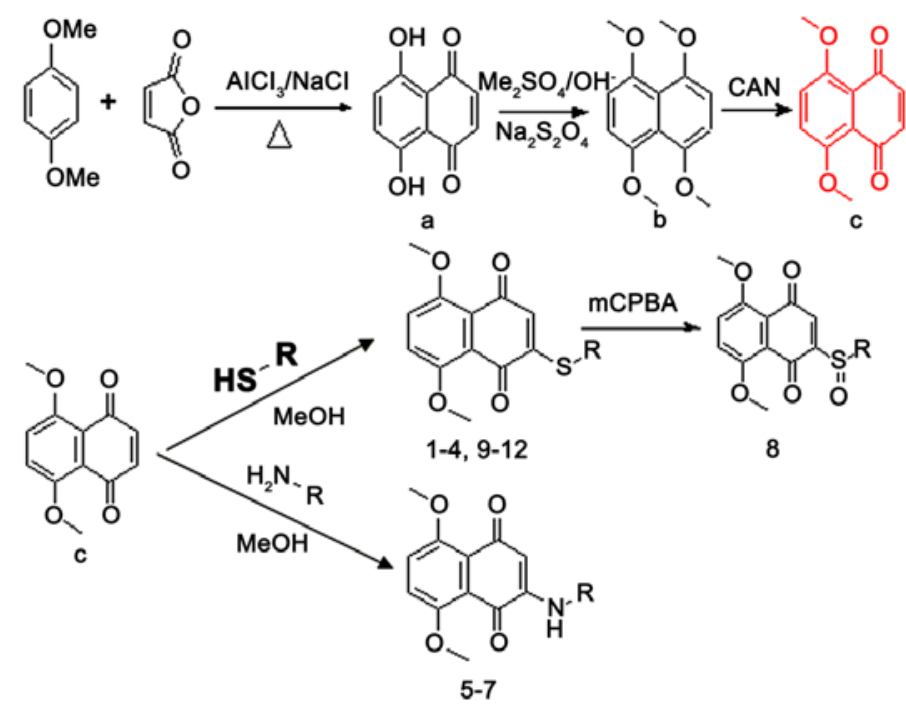

B

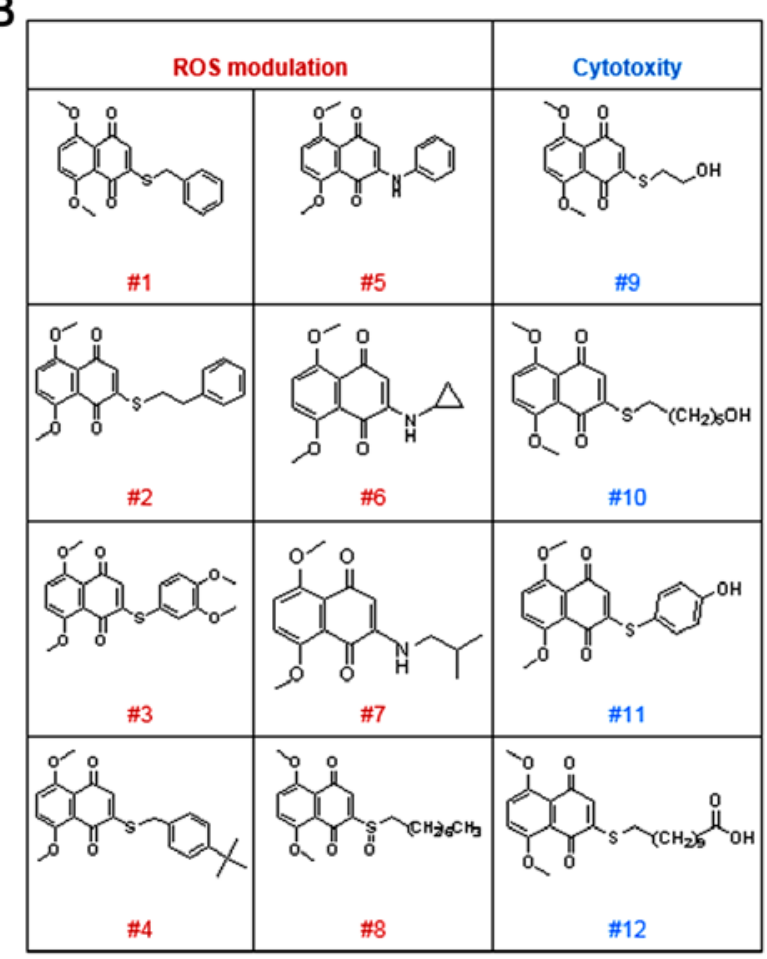

Figure 1. Synthetic schemes and structures of the 12 different 5,8-dimethoxy-1,4-naphthoquinone derivatives. (A) Synthetic schemes of 5,8-dimethoxy-1,4-naphthoquinone derivatives. Compounds were synthesized by condensation, methylation, oxidation, and Michael addition reactions. (B) structures of 12 different 5,8-dimethoxy-1,4-naphthoquinone derivatives. OMe, methoxy; $\mathrm{MeOH}$, Methanol; $\left(\mathrm{CH}_{2}\right)_{5} \mathrm{OH}$, hydroxy pentyl; $\left(\mathrm{CH}_{2}\right)_{6} \mathrm{CH}_{3}$, heptyl; $\left(\mathrm{CH}_{2}\right)_{9}$, nonyl; $\mathrm{O}$, oxygen; $\mathrm{AlCl}_{3}$, aluminum chloride; $\mathrm{NaCl}$, sodium chloride; $\mathrm{OH}$, hydroxide; $\mathrm{Me}_{2} \mathrm{SO}_{4}$, dimethyl sulfate; $\mathrm{Na}_{2} \mathrm{~S}_{2} \mathrm{O}_{4}$, sodium dithionite; $\mathrm{CAN}$, Cerium (IV) diammonium nitrate; mCPBA, meta-Chloroperoxybenzoic acid; S, sulphur; HS, hydrosulfide; R, functional group; $\mathrm{H}_{2} \mathrm{~N}$, nitrogen hydride; $\mathrm{NH}$, amine; ROS, reactive oxygen species.

Synthesis of DMNQ derivative \#8. 2-Heptyltho-DMNQ solution (300 mg, $1.37 \mathrm{mmol})$ in $40 \mathrm{ml}$ dichloromethane was added to $1.65 \mathrm{mmol} 3$-chloroperoxybenzoic acid (Shanghai Aladdin Bio-Technology Co., Ltd.). The reaction mixture was stirred at room temperature for $2.5 \mathrm{~h}$. The resulting solution was added to $40 \mathrm{ml}$ saturated sodium chloride solution. The resulting mixture was stirred for a few minutes, extracted with $\mathrm{CH}_{2} \mathrm{Cl}_{2}$, concentrated and recrystallized in $\mathrm{EtOH}$ to produce the target compound \#8 (Fig. 1B-\#8).

The structures of compounds \#1 were characterized by nuclear magnetic resonance (NMR) and mass spectroscopy.

Chemicals. The following chemicals were used in the current study: DMEM (Invitrogen; Thermo Fisher Scientific, Inc.), FBS (Cytiva), penicillin $(100 \mathrm{U} / \mathrm{ml})$ and streptomycin (100 mg/ml; Beijing Solarbio Science \& Technology, Co., Ltd.), MTT (Sigma-Aldrich; Merck KGaA), an Annexin V-FITC and propidium iodide (PI) detection kit (Beijing Solarbio Science \& Technology, Co., Ltd.), dihydroethidium (DHE; Beyotime Institute of Biotechnology), Hoechst 32258 (Thermo Fisher Scientific, Inc.), N-acetyl-L-cysteine (NAC; Beijing Solarbio Science \& Technology, Co., Ltd.), horseradish peroxidase-conjugated goat anti-rabbit immunoglobulin (Ig)G and anti-mouse IgG (Sangon Biotech, Co., Ltd.).

Cell culture. The following cell lines were used: NIH3T3 mouse embryonic fibroblasts (NC), H-Ras ${ }^{\mathrm{G} 12 \mathrm{~V}}$-transfected NIH3T3 mouse embryonic fibroblasts (NR), HepG2 human liver cancer $(\mathrm{HC})$ cells and $\mathrm{H}-\mathrm{Ras}^{\mathrm{G} 12 \mathrm{~V}}$-transfected HepG2 human liver cancer cells (HR). All cell lines were provided by Dr Dae-Yeul Yu (Aging Intervention Research Center, Korea Research Institute of Bioscience and Biotechnology, Daejeon, Korea). Cells were all cultured in DMEM with $10 \%$ (v/v) FBS and maintained in a culture environment of $37^{\circ} \mathrm{C}$ and $5 \% \mathrm{CO}_{2}$. The culture medium was replaced once a day and cells were sub-cultured every 3 days. Cells were treated with $5 \mathrm{mM}$ NAC for $30 \mathrm{~min}$ prior to treatment with $8 \mu \mathrm{M}$ BZNQ.

Cytotoxicity analysis of the 12 different 5,8-dimethoxy-1,4-naphthoquinone derivatives. NC and NR cells were seeded on 96-well plates $(10,000$ cells/well) and cultured for $24 \mathrm{~h}$ at $37^{\circ} \mathrm{C}$ in the presence of the 12 different 5,8-dimethoxy-1,4-naphthoquinone derivatives $(0,10,25$ and $50 \mu \mathrm{M})$. A total of $10 \mu 1(0.5 \mathrm{mg} / \mathrm{ml})$ MTT reagent was added and absorbance was measured at a wavelength of $490 \mathrm{~nm}$ using a UV MAX kinetic microplate reader (Molecular Devices, LLC.) to determine the accumulation of formazan. The purple formazan was subsequently dissolved using DMSO. The $\mathrm{IC}_{50}$ values were obtained using SigmaPlot Version 10.0 software (Systat Software Inc.).

Cell viability assay. MTT assays were used to analyze cell viability. NC, NR, HC and HR cells were seeded on 96-well plates (seeding density, 10,000 cells/well) and cultured for $24 \mathrm{~h}$ at $37^{\circ} \mathrm{C}$ in the presence of 2-benzylthio-5,8-dimethoxynaphthalene-1,4-dione (BZNQ) at concentrations of $0,2,4,6,8$ 
and $10 \mu \mathrm{M}$ in NC and NR cells. For HC and HR cells, BZNQ was administered at $0,2,4,6,8,10$ and $20 \mu \mathrm{M}$. The $0 \mu \mathrm{M}$ (untreated) group was used as the control. Following this, $10 \mu 1$ $(0.5 \mathrm{mg} / \mathrm{ml})$ of MTT reagent was added and the absorbance was measured at the wavelength of $490 \mathrm{~nm}$ using a UV MAX kinetic microplate reader (Molecular Devices, LLC.) to determine the accumulation of formazan. The MTT reagent was dissolved with DMSO.

Early and late apoptosis detection using Annexin V-FITC/PI. $\mathrm{NC}, \mathrm{NR}, \mathrm{HC}$ and HR cells treated with BZNQ were harvested by trypsin and then suspended in PBS. Apoptosis was measured by staining with Annexin V-FITC/PI for $15 \mathrm{~min}$ at room temperature. The number and proportion of positively-labeled cells were analyzed by flow cytometry (FACSCalibur; BD Biosciences). The results were analyzed using the WinMDI software (version 2.9; BD Biosciences).

Detection of ROS production. HC and HR cells were treated with BZNQ for $12 \mathrm{~h}$. Cells were subsequently fixed with $4 \%$ paraformaldehyde for $10 \mathrm{~min}$ at room temperature. The changes in cellular ROS levels were determined using $5 \mu \mathrm{M}$ DHE for $15 \mathrm{~min}$ at $37^{\circ} \mathrm{C}$. Nuclei were visualized using Hoechst 32258 staining. Nuclear staining was observed qualitatively under a fluorescence microscopy (EVOS ${ }^{\circledR} \mathrm{xl}$ core cell culture microscope; Advanced Microscopy Group) following 20 min of incubation with the Hoechst dye at $37^{\circ} \mathrm{C}$.

Western blotting. For the isolation of proteins, cells was lysed in ice-cold cell extraction buffer [20 mM HEPES (pH 7.0), $50 \mathrm{mM} \mathrm{NaCl}, 10 \%$ Triton X-100, $10 \%$ Glycerol, $1 \mathrm{mM} \beta$-ME and a protease inhibitor cocktail tablet; Roche Diagnostics $\mathrm{GmbH}$ ] for $30 \mathrm{~min}$. Lysates were centrifugated at $13,200 \mathrm{x} \mathrm{g}$ and $4^{\circ} \mathrm{C}$ for $20 \mathrm{~min}$. Total protein $(2 \mu \mathrm{g} / \mu \mathrm{l})$ quantification was determined by a Bradford protein assay using an ultraviolet spectrophotometer (Aoyi Instruments Co., Ltd.). Denatured protein of cell lysates were separated using $12 \%$ SDS-PAGE and transferred to nitrocellulose membranes (EMD Millipore). The membranes were blocked with 5\% skim milk (BD Biosciences) for $1 \mathrm{~h}$ at room temperature. The membranes were incubated with primary antibodies against H-Ras (cat. no bs-1071; BIOSS; 1:1,000), protein kinase B (AKT; cat. no. sc-8044; Santa Cruz Biotechnology, Inc.; 1:2,000), p-AKT (cat. no. sc-101629; Santa Cruz Biotechnology, Inc.; 1:2,000), extracellular regulated kinase (ERK; cat. no. sc-135900; Santa Cruz Biotechnology, Inc.; 1:2,000), p-ERK (cat. no. sc-7383; Santa Cruz Biotechnology, Inc.; 1:2,000), glycogen synthase kinase $3 \beta$ (GSK3 $\beta$; cat. no. AF1543; Beyotime Institute of Biotechnology, Inc.; 1:2,000). p-GSK3 $\beta$ (Ser9; cat. no. AF5830; Beyotime Institute of Biotechnology, Inc.; 1:2,000), $\beta$-catenin (cat. no. AF1189; Beyotime Institute of Biotechnology, Inc.; 1:2,000), B-cell lymphoma-2 (Bcl-2; cat. no. sc-7382; Santa Cruz Biotechnology, Inc.; 1:2,000), Bcl-2 associated agonist of cell death (Bad; cat. no. 8044; Santa Cruz Biotechnology, Inc.; 1:2,000), $\beta$-actin (cat. no. 3700; Cell Signaling Technology, Inc.; dilution, $1: 2,000)$ at $4^{\circ} \mathrm{C}$ overnight. The membranes were washed five times with TBST [10 mM Tris $\mathrm{HCl}$ (pH 7.5), $150 \mathrm{mM} \mathrm{NaCl}$ and $0.2 \%$ Tween-20] to remove excess antibodies and then incubated for $1 \mathrm{~h}$ at room temperature with horseradish peroxidase conjugated goat anti
Table I. $\mathrm{IC}_{50}$ values of the derived compounds on $\mathrm{NC}$ and $\mathrm{NR}$ cells.

\begin{tabular}{lrr}
\hline Compound & $\mathrm{NC}$ & $\mathrm{NR}$ \\
\hline$\# 1$ (BZNQ) & 12.40 & $4.73^{\mathrm{a}}$ \\
$\# 2$ & 39.31 & 35.86 \\
$\# 3$ & $<10.00$ & $<10.00$ \\
$\# 4$ & 16.42 & 24.37 \\
$\# 5$ & $>50.00$ & $>50.00$ \\
$\# 6$ & $>50.00$ & $>50.00$ \\
$\# 7$ & $>100.00$ & $>100.00$ \\
$\# 8$ & $<1.00$ & $<1.00$ \\
$\# 9$ & $<1.00$ & $<1.00$ \\
$\# 10$ & 5.37 & 7.53 \\
$\# 11$ & $>30.00$ & $21.52^{\mathrm{a}}$ \\
$\# 12$ & 22.50 & 12.39 \\
\hline
\end{tabular}

${ }^{\mathrm{a}} \mathrm{P}<0.01 . \mathrm{IC}_{50}$, half maximal inhibitory concentration $(\mu \mathrm{M}) ; \mathrm{NC}$, NIH3T3 mouse embryonic fibroblasts; NR, H-Ras ${ }^{\mathrm{G} 12 \mathrm{~V}}$-transfected NIH3T3 mouse embryonic fibroblasts; BZNQ, 2-benzylthio-5,8dimethoxynaphthalene-1,4-dione.

mouse and rabbit IgG secondary antibodies(cat. no. D110087 and D110058; Shanghai Sangon Biotech Co., Ltd.; 1:5,000). Bands of antibody-specific binding proteins were visualized by a chemiluminescence detection system (GE Healthcare) and densitometry was analyzed using Image J version 1.52a software (National institutes of Health).

Statistical analysis. Data are presented as the mean \pm SEM from at least three independent repeated experiments. Two-way ANOVA was used to analyze the changes across time and differences between groups with the Tukey's honestly significant difference test used as the post-hoc test $(\alpha=0.05)$. $P<0.05$ was considered to indicate a statistically significant difference.

\section{Results}

Effect of BZNQ on cell viability. According to the synthetic methodology provided above, a total of 9 derivatives with a redox center $S$ atom and 3 alkylamine derivatives that were able to clear ROS in cells were designed (Fig. 1A). The structure of each 5,8-dimethoxy-1,4-naphthoquinone derivative is provided in Fig. 1B. The results indicated that compounds \#1-8 may be associated with ROS modulations, while compounds \#9-12 may be involved in cell cytotoxicity (Fig. 1B). To examine the cytotoxicity of the synthesized compounds, the $\mathrm{NC}$ and NR NIH3T3 cells were treated with derived compounds \#1-12 and the concentrations of $\mathrm{IC}_{50}$ for each compound were evaluated using MTT assays (Table I). The results demonstrated that at low concentrations, BZNQ exhibited higher cytotoxic activity in both NC and NR cells compared with the rest of the compounds. Compared with \#11, \#1 demonstrated lower dose targeting to HRAS. Additionally, the lower dosage produced fewer side effects. \#1 was therefore selected for further study. Furthermore, compounds \#2-4 and \#8-10 demonstrated significant activities in NC and NR cells; however, there were 
A<smiles>COc1ccc(OC)c2c1C(=O)C=C(SCc1ccccc1)C2=O</smiles>

C
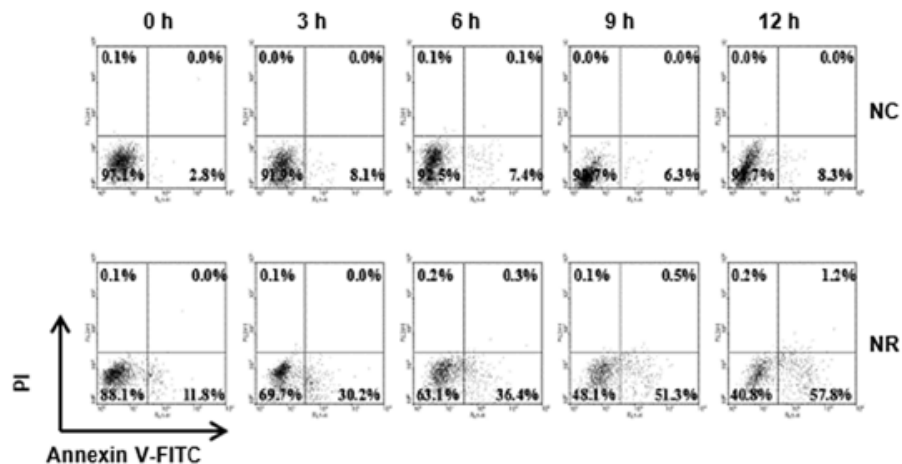
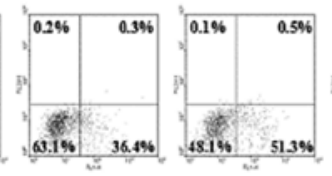

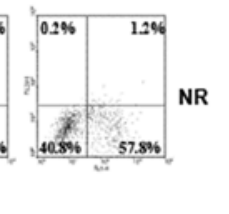

B

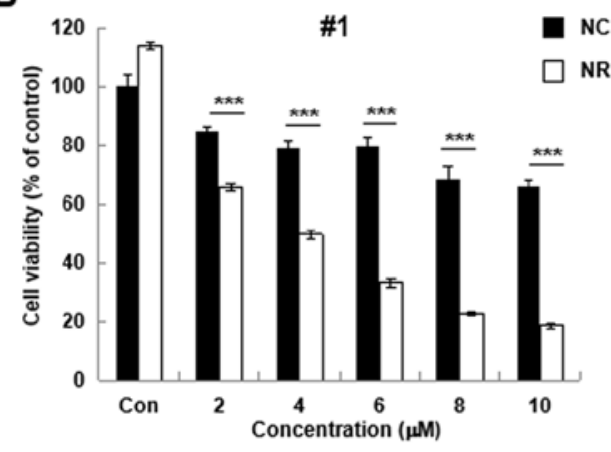

D

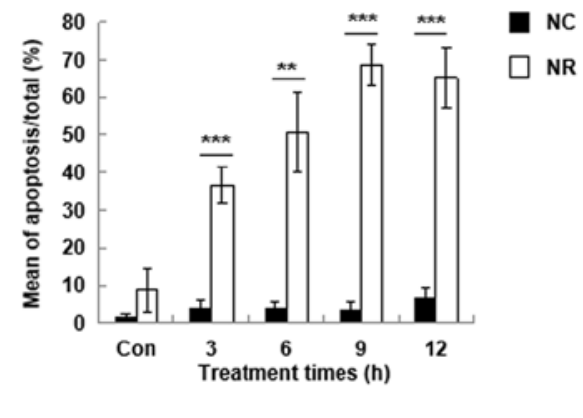

Figure 2. Effect of BZNQ on cellular viability and apoptosis. (A) The structure of BZNQ as obtained from nuclear magnetic resonance analysis. (B) The effect of BZNQ on NC (black bars) and NR (white bars) cell viability was detected using MTT assays. The untreated NC group was used as the control group. (C) NC and NR cells were treated with BZNQ and cellular apoptosis was examined with Annexin V-FITC/PI kit using flow cytometry. (D) The level of apoptosis was presented as the mean \pm standard deviation. Experiments were performed in triplicate. ${ }^{* *} \mathrm{P}<0.01,{ }^{* * * *} \mathrm{P}<0.001$. BZNQ, 2-benzylthio-5,8-dimethoxynaphthalene-1,4-dione; NC, NIH3T3 mouse embryonic fibroblast cell line; NR, H-Ras ${ }^{\mathrm{G} 12 \mathrm{~V}}$-transfected NIH3T3 mouse embryonic fibroblast cell line; PI, propidium iodide; O, oxygen; S, sulphur; Con, control.

no significant differences in cytotoxicity effects between NC and NR cells (data not shown). The results indicated that the different modulation of the substitution groups at the specified positions exhibited various inhibiting activities in cells. Therefore, the current study focused subsequent experiments on BZNQ to elucidate the possible mechanisms of action.

BZNQ induces apoptosis in Ras-transfected NIH3T3 cells. To investigate the structure of BZNQ, NMR spectra were evaluated. According to the NMR spectra examination, the \#1 compound as BZNQ: ${ }^{1} \mathrm{H}-\mathrm{NMR}\left(\mathrm{CDCl}_{3}, 400 \mathrm{MHz}\right)$ 87.40-7.28 [multiplet (m), 5 hydrogen $(\mathrm{H})$ ], 6.98-6.80 (m, 2H), 5.99 [singlet (s), 1H] $3.94(\mathrm{~s}, 6 \mathrm{H}), 3.63(\mathrm{~s}, 2 \mathrm{H})$; 13C NMR $\left(\mathrm{CDCl}_{3}, 100 \mathrm{MHz}\right)$ d 187.7 [C (carbon)-1], 180.7 (C-4), 154.3 (C-5), 154.1 (C-8), 153.7 (C-2), 135.2 (C-1'), 134.5 (C-3), 129.0 (C-3'), 129.0 (C-5'), 128.9 (C-2'), 128.9 (C-6'), 128.7 (C-4'), 128.1 (C-7), 127.5 (C-6), 121.1 (C-9), $119.6(\mathrm{C}-10), 56.9\left(\mathrm{OCH}_{3}\right), 56.7\left(\mathrm{OCH}_{3}\right), 35.4\left(\mathrm{CH}_{2}\right)$ and $\mathrm{m} / \mathrm{z} 362.63$ [Molecule (M)+Na] ${ }^{+}$(Fig. 2A).

Following this, the effect of BZNQ on cellular apoptosis in NC and NR cells was examined. The results indicated that BZNQ induced NR cell apoptosis in a dose-dependent manner (Fig. 2B). Furthermore, flow cytometry analysis indicated that BZNQ treatment significantly increased NR cell apoptosis compared with NC cells (Fig. 2C and D).

$B Z N Q$ induces cellular apoptosis through the AKT, ERK and GSK signaling pathways. To elucidate the possible signaling pathways by which BZNQ induces NR cell apoptosis, H-Ras protein expression in cells treated with BZNQ for $24 \mathrm{~h}$ was evaluated. The results demonstrated that BZNQ treatment significantly downregulated $\mathrm{H}-\mathrm{R}$ as protein expression levels in NR cells (Fig. 3A). Due to these results, the known Ras-mediated downstream signaling pathways, including AKT, ERK and GSK, as well as $\beta$-catenin activation, were evaluated. The results revealed that BZNQ treatment significantly downregulated AKT, ERK and GSK $3 \beta$ protein phosphorylation in NR cells (white bar) compared with NC cells (black bar; Fig. 3B).

$B Z N Q$ increases cellular apoptosis and ROS accumulation in HepG2 liver cancer cells. Since BZNQ increased cell apoptosis by targeting Ras signaling proteins, the cytotoxic effects of BZNQ on HC and HR liver cancer cells was evaluated. BZNQ exhibited highly marked cytotoxicity in both HC and HR cells, as shown by MTT assays. After BZNQ treatment, fluorescence intensity was increased when compared with untreated cells, as observed by fluorescent microscopy (Fig. 4C) and flow cytometry analysis (Fig. 4D) by detecting DHE fluorescence intensity. The results demonstrated that BZNQ treatment elevated cellular ROS accumulations in HC and HR cells.

Scavenging ROS levels decreases BZNQ-induced cellular apoptosis by upregulating the protein expression of Bad. 
A

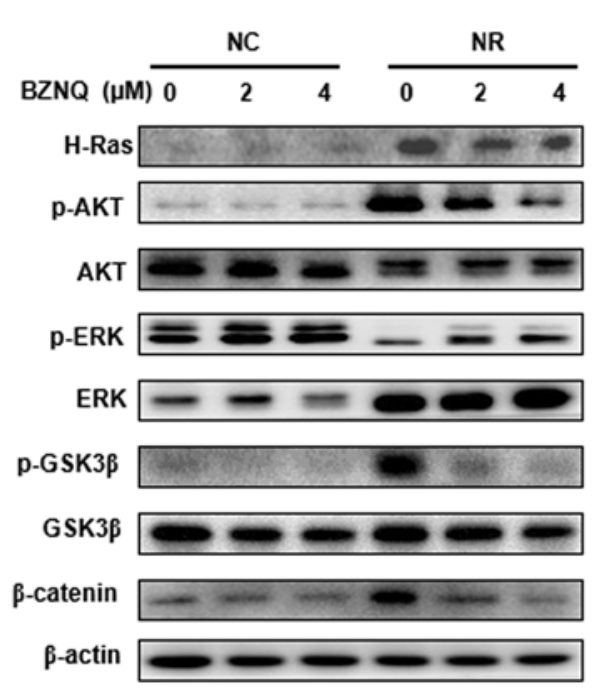

B
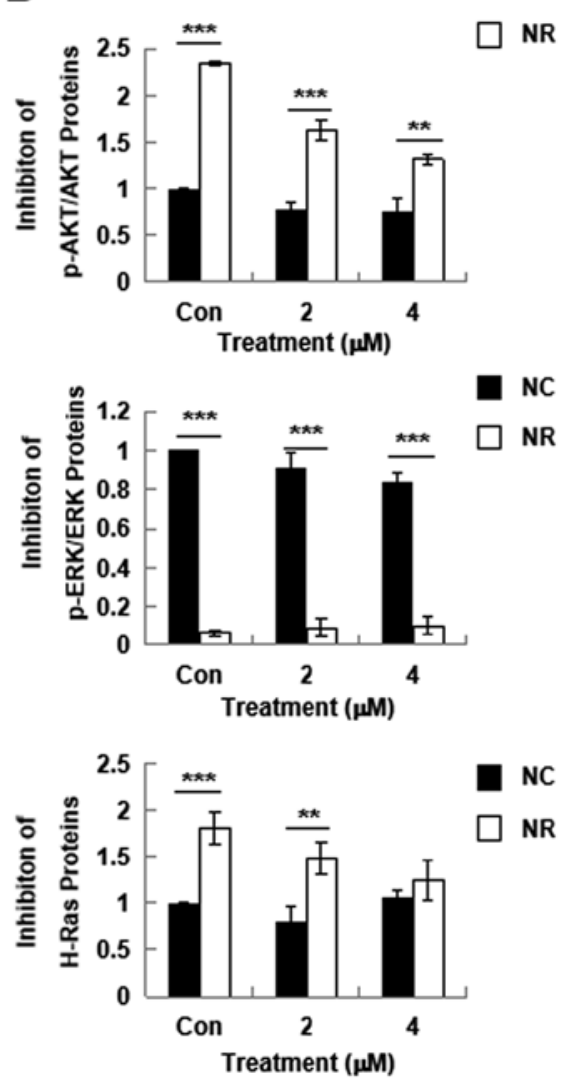

- NC

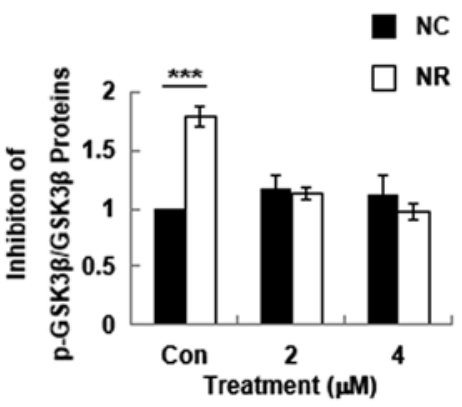

NC

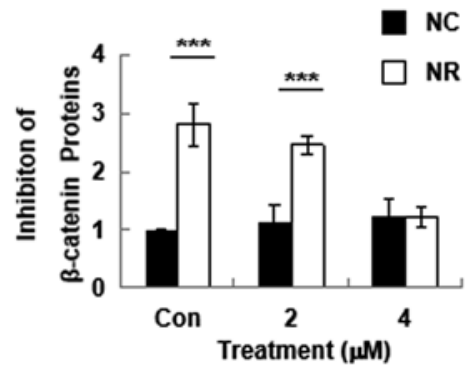

Figure 3. Effect of BZNQ on H-Ras protein expression and Ras-mediated downstream signaling. (A) NC and NR cells were treated with indicated concentrations of BZNQ for $24 \mathrm{~h}$. H-Ras, p-AKT, AKT, p-ERK, ERK, p-GSK3 $\beta$, GSK3 $\beta$, $\beta$-catenin and $\beta$-actin protein expression levels were detected via western blotting. (B) Fold increase in protein expression levels. ${ }^{* *} \mathrm{P}<0.01,{ }^{* * *} \mathrm{P}<0.001$. Experiments were performed in triplicate. BZNQ, 2-benzylthio-5,8-dimethoxynaphthalene-1,4-dione; NC, NIH3T3 mouse embryonic fibroblast cell line; NR, H-Ras ${ }^{\mathrm{G} 12 \mathrm{~V}}$-transfected NIH3T3 mouse embryonic fibroblast cell line; AKT, protein kinase B; ERK, extracellular regulated kinase; GSK3 $\beta$, glycogen synthase kinase $3 \beta$.

To understand the role of ROS on BZNQ-induced cellular apoptosis, HC and HR cells were pretreated with NAC, a ROS scavenger, for $30 \mathrm{~min}$, followed with BZNQ treatment. NAC pre-treatment decreased cellular ROS levels and apoptosis in HC and HR cells (Fig. 5A-C). Furthermore, apoptosis-related protein expression levels, including Bcl-2 (anti-apoptotic) and Bad (pro-apoptotic), were evaluated following the BZNQ treatment. The results indicated that BZNQ treatment upregulated Bad protein expression and slightly downregulated the $\mathrm{Bcl}-2$ expression in $\mathrm{HC}$ and $\mathrm{HR}$ cells (Fig. 5D).

\section{Discussion}

Shikonin is a small-molecule compound extracted from the natural plant Arnebia euchroma and induces tumor cell apoptosis (23-25), inhibits DNA topoisomerase (26) and protein tyrosine kinase (26), represses human telomerase activity (27), suppresses tumor angiogenesis (28), alters tumor cell signal transduction and activates mitogen activated protein kinase (MAPK) through chemical protection and induces antimitotic effects (29). Furthermore, shikonin influences the metabolism, proliferation, differentiation, signal transmission, gene expression, cell growth, invasion and metastasis of tumor cells (30-32). However, due to the strong cytotoxicity and side effects of shikonin, including nausea, vomiting and loss of appetite, it has not been widely used in clinical practice (33). With further research into the mechanisms of action of shikonin, it has been reported that the toxic side effects of its derivatives are greatly reduced following the addition of the methylated 5' and 8' hydroxyl groups to methoxy groups (34). Moreover, naphthoquinone derivatives are more convenient for the latter modification and therefore, has more structural advantages in the synthesis of new compounds. Previous results have demonstrated that naphthoquinone derivatives specifically inhibit the p53-Snail binding in K-Ras ${ }^{\mathrm{G} 12 \mathrm{D}}$ mutant A549 cells to induce cell apoptosis (35), demonstrating that naphthoquinone derivatives have the potential to target the Ras signaling pathway.

1,4-Naphthoquinone is the main component of Arnebia purpurea and widely exists in nature as a small molecular compound with quinone moiety (36). Generally, when two kinds of substituents contain the same hydrocarbon group, the cytotoxicity of mercaptan derivatives is stronger compared with amino derivatives (37). While amino derivatives have anti-inflammatory effects (38), mercaptan derivatives have better anti-tumor $(39,40)$ and anti-malaria activity (41,42). Bielitza et al (43) reported that benzyl carbon in naphthoquinone derivatives participates in the oxidation-reduction cycle of NADPH and that benzyl carbon 
A

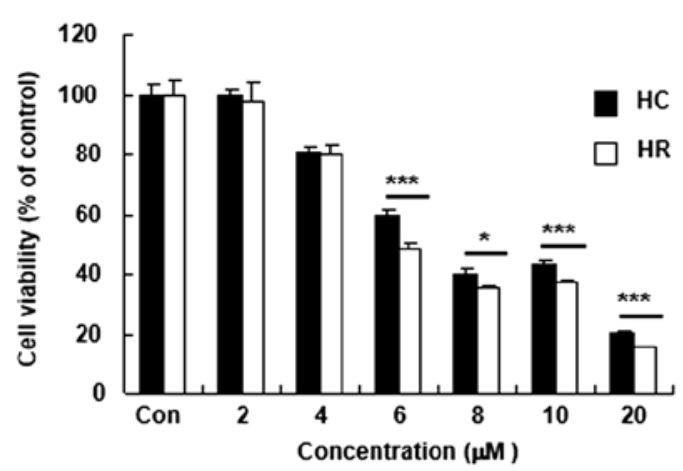

B

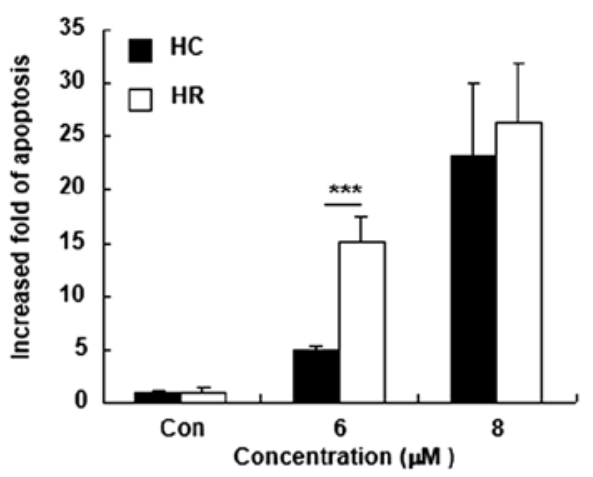

C

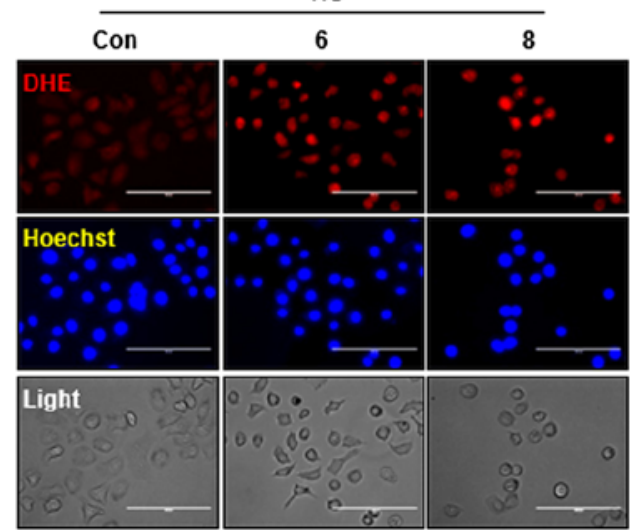

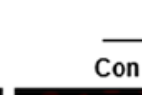

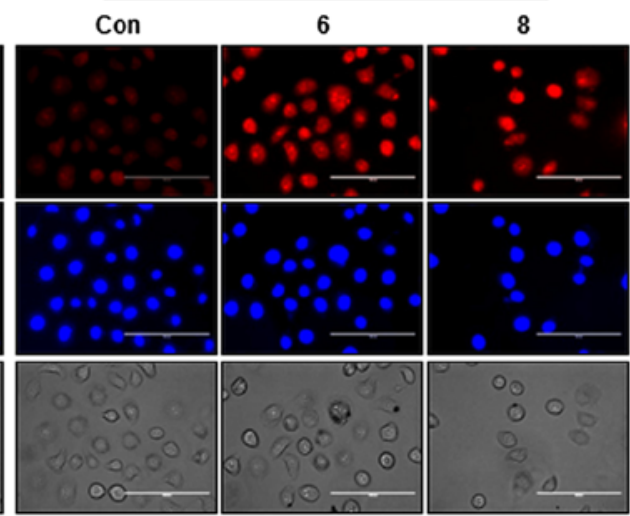

D

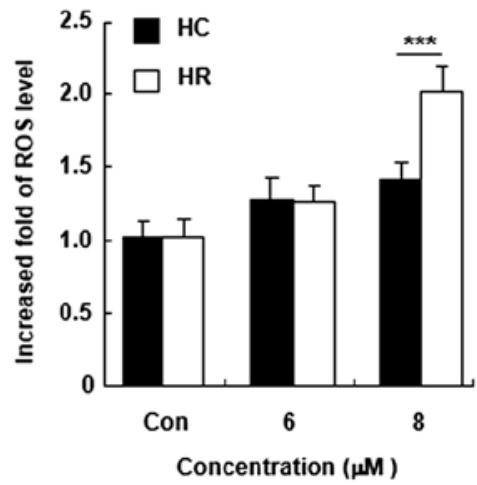

Figure 4. Effect of BZNQ on cancer cell viability, apoptosis and ROS levels. (A) HC and HR cells were treated with the indicated concentrations of BZNQ and cell viability was examined using MTT assays. (B) Cellular apoptosis was assayed using an Annexin V/propidium iodide staining kit and measured using flow cytometry. The increased fold of apoptosis was presented as mean \pm SD. (C) Cellular ROS levels were detected using DHE staining and observed with fluorescent microcopy. Scale bar, $100 \mu \mathrm{M}$. (D) Fold increase of ROS levels was presented as mean \pm SD. All experiments were performed in triplicate. ${ }^{*} \mathrm{P}<0.05,{ }^{* * *} \mathrm{P}<0.001$. BZNQ, 2-Benzylthio-5,8-dimethoxynaphthalene-1,4-dione; ROS, reactive oxygen species; HC, HepG2 human liver cancer cell line; HR, H-Ras ${ }^{\mathrm{G} 12 \mathrm{~V}}$-transfected HepG2 human liver cancer cell line; DHE, dihydroethidium; SD, standard deviation; Con, control.

can be oxidized to carbonyl by hydroxylation or peroxidation. If the para position of the benzene ring contains a tert-butyl group, it can reduce the toxicity of compounds (44). The substituent alkyl terminal containing hydroxyl or carboxyl group exhibits strong cytotoxicity (45). The current study synthesized and reported several groups of these kinds of compounds which exhibited significant anticancer property. In order to further investigate this series of DMNQ compounds, group compounds that contain a sulfur atom linked between naphthnoquinone core and linear substitutes were designed. The sulfur atom can be used as an oxidation-reduction center to eliminate ROS in cells (46). Several substitutes, including benzyl, butyl and cyclo propyl, which are normally selected to optimize the property of designed compounds, were used in the current study. The results demonstrated that benzyl substituted compound BZNQ demonstrated excellent effects, with increased cytotoxity in H-Ras ${ }^{\mathrm{G} 12 \mathrm{~V}}$ mutated cells and a lower concentration.

In the current study, 12 DMNQ derivatives were designed, including BZNQ. Among the 12 kinds of derivatives, BZNQ had the highest cytotoxic effect in NR cells compared with $\mathrm{NC}$ cells compared with all other compounds from the $\mathrm{IC}_{50}$ value. Furthermore, compounds \#2-4 and \#8-10 demonstrated significant activities in NC and NR cells; however, there were no significant differences in cytotoxicity effects between NC and NR cells (data not shown), indicating that the different modulation of the substitution groups at the positions exhibited various inhibiting activities in cells. The possible molecular mechanisms that rely on structure-activity relationships should be studied further.

The intracellular signaling pathways that regulate apoptosis are diverse and complex. Generally, when Ras signaling has been activated, the downstream MAPK signaling pathway must also be activated (47). However, it has been reported that $\mathrm{H}-\mathrm{Ras}^{\mathrm{G} 12 \mathrm{~V}}$ preferentially activates the PI3K/AKT signaling pathway to promote cell survival following starvation and activated AKT inhibits s621 phosphorylation of RAF and downregulates ERK phosphorylation (48-50). Furthermore, NF- $\kappa \mathrm{B}$ was revealed to be an important downstream signal molecule for AKT to regulate cell anti-apoptotic signaling and inhibiting $\mathrm{NF}-\kappa \mathrm{B}$ blocked the anti-apoptotic signals regulated by PDG/PI3K/AKT $(51,52)$. Furthermore, BZNQ inhibited AKT and GSK3 $\beta$ S9 phosphorylation, which resulted in promotion of $\beta$-catenin in NIH3T3 cells These changes in the activity of signaling pathways promoted apoptosis-related protein expression levels (Bad upregulation and $\mathrm{Bcl}-2$ downregulation), which led to cellular apoptosis. Additionally, Ras, a member of MAPK upstream signal, can cause the activation of downstream signals (53). It has also been reported that AKT phosphorylates Raf, which activates ERK phosphorylation (54) and that there have alternative 
A

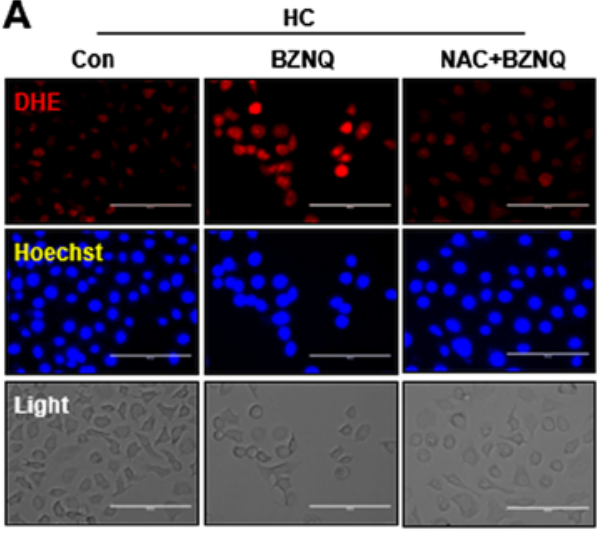

C

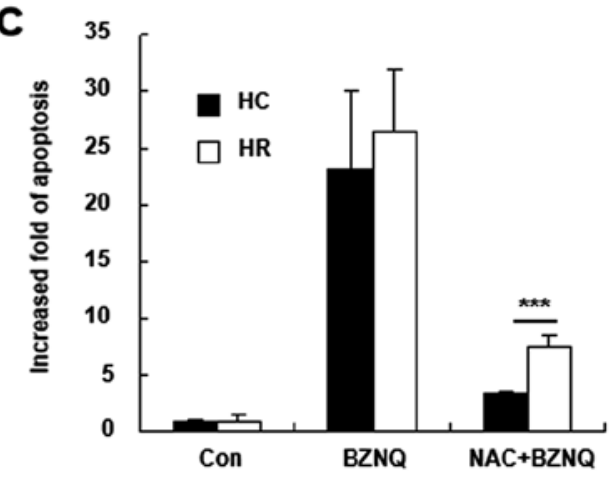

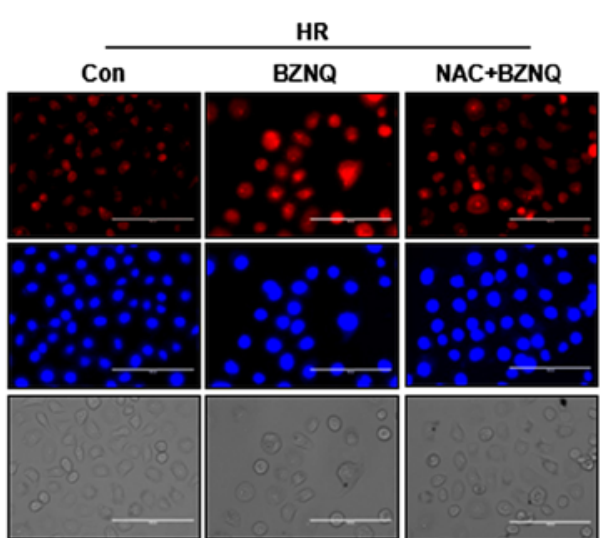

B

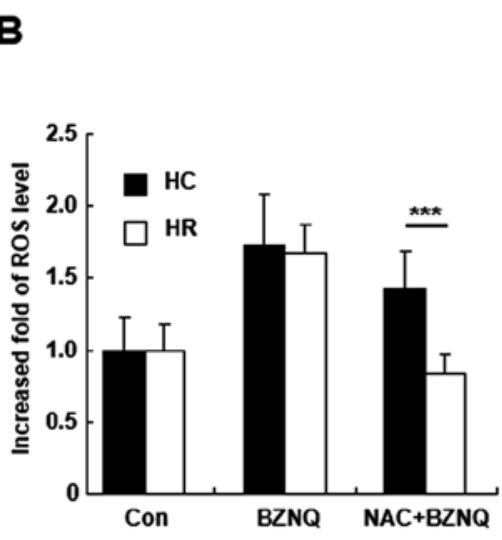

D
HC

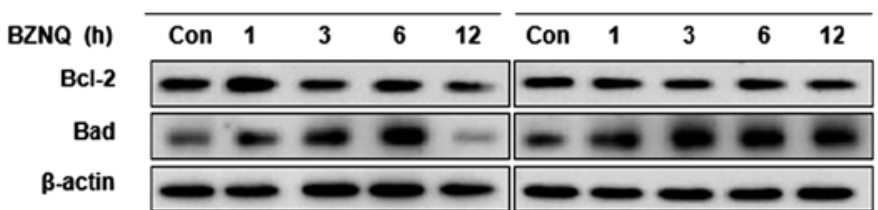

Figure 5. ROS scavenging inhibited BZNQ-induced cellular apoptosis. (A) HC and HR cells were pre-treated with 5 mM NAC, an ROS scavenger, for 30 min, followed by BZNQ treatment. ROS levels were detected by DHE staining and observed with fluorescent microcopy. Scale bar, $100 \mu \mathrm{M}$. (B) Cellular ROS levels were assayed with DHE staining following NAC and BZNQ treatment and measured using flow cytometry. Fold increase in ROS levels was presented as mean \pm SD. (C) Cellular apoptosis was assayed with Annexin V/propidium iodide (staining kit following NAC and BZNQ treatment and measured using flow cytometry assay. Fold increase in apoptosis was presented as mean \pm SD. (D) The protein expression levels of Bcl-2 and Bad were examined following BZNQ treatment in HC and HR cells by western blotting. Experiments were performed in triplicate. ${ }^{* * *} \mathrm{P}<0.001$. ROS, reactive oxygen species; BZNQ, 2-benzylthio-5,8-dimethoxynaphthalene-1,4-dione; HC, HepG2 human liver cancer cell line; HR, H-Ras ${ }^{\mathrm{G} 12 \mathrm{~V}}$-transfected HepG2 human liver cancer cell line; NAC, N-acetyl-L-cysteine; DHE, dihydroethidium; SD, standard deviation; Bcl-2, B-cell lymphoma 2; Bad, Bcl-2 associated agonist of cell death; Con, control.

active phenomenon between ERK and AKT, such as ERK upregulation and AKT downregulation (55). The current study did not result in direct evidence to clarify the differences in the activation of H-Ras and p-ERK expression levels. This should be further investigated in future studies.

Since BZNQ exhibited strong cytotoxic effects by targeting Ras signaling, the current study hypothesized that it may also have a toxic effect on cancer cells, particularly in Ras mutated cancer cells. Therefore, the effect of BZNQ in HC and HR cells was examined. The observed results demonstrated that there was a high toxic effect on BZNQ on HC and HR cells, there were significant differences in cellular apoptosis and ROS levels between HC and HR cells. This is closely associated with the 5,8-dimethoxynaphthalene-1,4-dione core and benzyl group of BZNQ as these subunits may serve an important role in the increase of intracellular ROS levels and cytotoxicity (56). The current study speculates that BZNQ promoted the apoptosis of Ras mutant cell lines by inhibiting the expression of Ras proteins and increasing the level of ROS in $\mathrm{H}-\mathrm{RasG}^{12 \mathrm{~V}}$ transfected cells. The results indicated that the Ras signaling pathway may serve different roles in healthy cells and cancer cells. The possible mechanisms should be studied further.

In conclusion, based on the analysis of the structure-activity relationship of DMNQ derivatives, the current study designed, synthesize and screened compounds that specifically regulated the Ras mutation signal. The results confirmed the effects of the compounds on the apoptosis signaling pathway AKT/GSK3 $\beta$ / $\beta$-catenin, which is downstream of the Ras signaling pathway. Although there was no direct evidence of how BZNQ induced cell death in Ras-mutated cells, the results demonstrated that the apoptotic levels of NC, NR, HC and HR cells were significantly different following BZNQ treatment, resulting in significant changes in the downstream signal of Ras. This indicated that $\mathrm{H}-\mathrm{Ras}^{\mathrm{G} 12 \mathrm{~V}}$ transfected cells were more sensitive to BZNQ. The specific mechanism needs further study. These results indicated that the novel derivative synthesized based on DMNQ, BZNQ, may be a therapeutic drug for treating Ras-mediated tumorigenesis through the downregulation of $\mathrm{H}$-Ras protein expression and Ras-mediated signaling pathways.

\section{Acknowledgements}

Not applicable.

\section{Funding}

The current study was supported by the Natural Science Foundation of Heilongjiang Province of China (grant no. QC2016012), the University Nursing Program for Young 
Scholars with Creative Talents in Heilongjiang Province (grant no. CXRC2017016) the Heilongjiang Undergraduate Training Programs for Innovation and Entrepreneurship (grant no. 201910223027), and the Basic Science Research Program through the National Research Foundation of Korea (NRF) funded by the Ministry of Education (2020R1I1A2052417) and the grants from the Korean Research Institute of Bioscience and Biotechnology Research Initiative Program (KRIBB; KGM5162021, RBM0112011).

\section{Availability of data and materials}

The datasets used and/or analyzed during the current study are available from the corresponding author on reasonable request.

\section{Authors' contributions}

GNS, JL and YHJ analyzed the data and wrote the manuscript. GNS, TK and YHH designed experiments. HNS, YYH, MHJ, RL, WLL and YQZ performed the experiments. JBY, NNY, WDW, LYY and JSK developed novel software and performed simulations. TK and YHH conceived and supervised the study. All authors read and approved the final manuscript.

\section{Ethics approval and consent to participate}

Not applicable.

\section{Patient consent for publication}

Not applicable.

\section{Competing interests}

The authors declare that they have no competing interests.

\section{References}

1. Prior IA, Hood FE and Hartley JL: The frequency of ras mutations in cancer. Cancer Res 80: 2969, 2020

2. Yaeger R, Cowell E, Chou JF, Gewirtz AN, Borsu L, Vakiani E, Solit DB, Rosen N, Capanu M, Ladanyi M and Kemeny N: RAS mutations affect pattern of metastatic spread and increase propensity for brain metastasis in colorectal cancer. Cancer 121: 1195-1203, 2015.

3. Maertens $\mathrm{O}$ and Cichowski K: An expanding role for RAS GTPase activating proteins (RAS GAPs) in cancer. Adv Biol Regul 55: 1-14, 2014.

4. Grewal T, Koese M, Tebar F and Enrich C: Differential regulation of RasGAPs in cancer. Genes Cancer 2: 288-297, 2011.

5. Maurya HK, Gautam SK, Pratap R, Tandon VK, Kumar A, Kumar B, Saxena S, Tripathi D, Rajwanshi M, Das M and Ram VJ: Regioselective synthesis of polycyclic aza-oxa and aza-oxa-thia heteroarenes as Colo-205 and HepG2 carcinoma cells growth inhibitors. Eur J Med Chem 81: 367-377, 2014.

6. Inamdar GS, Madhunapantula SV and Robertson GP: Targeting the MAPK pathway in melanoma: Why some approaches succeed and other fail. Biochem Pharmacol 80: 624-637, 2010.

7. Ledford H: Cancer: The Ras renaissance. Nature 520: 278-280, 2015.

8. Zhang Y, Luo YH, Piao XJ, Shen GN, Wang JR, Feng YC, Li JQ, Xu WT, Zhang Y, Zhang T, et al: The design of 1,4-naphthoquinone derivatives and mechanisms underlying apoptosis induction through ROS-dependent MAPK/Akt/STAT3 pathways in human lung cancer cells. Bioorg Med Chem 27: 1577-1587, 2019.
9. Lin HY, Han HW, Wang YS, He DL, Sun WX, Feng L, Wen ZL, Yang MK, Lu GH, Wang XM, et al: Shikonin and 4-hydroxytamoxifen synergistically inhibit the proliferation of breast cancer cells through activating apoptosis signaling pathway in vitro and in vivo. Chin Med 15: 23, 2020.

10. Seetha A, Devaraj H and Sudhandiran G: Indomethacin and juglone inhibit inflammatory molecules to induce apoptosis in colon cancer cells. J Biochem Mol Toxicol 34: e22433, 2020.

11. Vukic MD, Vukovic NL, Obradovic A, Matic M, Djukic M and Avdovic E: Redox status, DNA and HSA binding study of naturally occurring naphthoquinone derivatives. EXCLI J 19: 48-70, 2020.

12. Guo C, He J, Song X, Tan L, Wang M, Jiang P, Li Y, Cao Z and Peng C: Pharmacological properties and derivatives of shikonin-A review in recent years. Pharmacol Res 149: 104463, 2019.

13. Lim ES, Rhee YH, Park MK, Shim BS, Ahn KS, Kang H, Yoo HS and Kim SH: DMNQ S-64 induces apoptosis via caspase activation and cyclooxygenase-2 inhibition in human nonsmall lung cancer cells. Ann N Y Acad Sci 1095: 7-18, 2007.

14. PLOS ONE Editors: Retraction: Ramentaceone, a naphthoquinone derived from drosera sp., induces apoptosis by suppressing PI3K/Akt signaling in breast cancer cells. PLoS One 14: e0226703, 2019.

15. Zhang Q, Dong J, Cui J, Huang G, Meng Q and Li S: Cytotoxicity of synthesized 1,4-naphthoquinone oxime derivatives on selected human cancer cell lines. Chem Pharm Bull (Tokyo) 66: 612-619, 2018.

16. Shahsavari Z, Karami-Tehrani F and Salami S: Shikonin induced necroptosis via reactive oxygen species in the T-47D breast cancer cell line. Asian Pac J Cancer Prev 16: 7261-7266, 2015.

17. Qiao C, Bi S, Sun Y, Song D, Zhang H and Zhou W: Study of interactions of anthraquinones with DNA using ethidium bromide as a fluorescence probe. Spectrochim Acta A Mol Biomol Spectrosc 70: 136-143, 2008.

18. Kobayashi K, Nishiumi S, Nishida M, Hirai M, Azuma T, Yoshida H, Mizushina Y and Yoshida M: Effects of quinone derivatives, such as 1,4-naphthoquinone, on DNA polymerase inhibition and anti-inflammatory action. Med Chem 7: 37-44, 2011.

19. Liu C, Shen GN, Luo YH, Piao XJ, Jiang XY, Meng LQ, Wang Y, Zhang Y, Wang JR, Wang H, et al: Novel 1,4-naphthoquinone derivatives induce apoptosis via ROS-mediated p38/MAPK, Akt and STAT3 signaling in human hepatoma Hep3B cells. Int J Biochem Cell Biol 96: 9-19, 2018.

20. Moore AR, Rosenberg SC, McCormick F and Malek S: RAS-targeted therapies: Is the undruggable drugged? Nat Rev Drug Discov 19: 533-552, 2020.

21. Aly AA, El-Sheref EM, Bakheet MEM, Mourad MAE, Bräse S, Ibrahim MAA, Nieger M, Garvalov BK, Dalby KN and Kaoud TS: Design, synthesis and biological evaluation of fused naphthofuro[3,2-c] quinoline-6,7,12-triones and pyrano[3,2-c] quinoline-6,7,8,13-tetraones derivatives as ERK inhibitors with efficacy in BRAF-mutant melanoma. Bioorg Chem 82: 290-305, 2019.

22. Kabakci Z, Käppeli S, Cantù C, Jensen LD, König C, Toggweiler J, Gentili C, Ribaudo G, Zagotto G, Basler K, et al: Pharmacophore-guided discovery of CDC25 inhibitors causing cell cycle arrest and tumor regression. Sci Rep 9: 1335, 2019.

23. Jeung YJ, Kim HG, Ahn J, Lee HJ, Lee SB, Won M, Jung CR, Im JY, Kim BK, Park SK, et al: Shikonin induces apoptosis of lung cancer cells via activation of FOXO3a/EGR1/SIRT1 signaling antagonized by p300. Biochim Biophys Acta 1863: 2584-2593, 2016.

24. Gara RK, Srivastava VK, Duggal S, Bagga JK, Bhatt M, Sanyal S and Mishra DP: Shikonin selectively induces apoptosis in human prostate cancer cells through the endoplasmic reticulum stress and mitochondrial apoptotic pathway. J Biomed Sci 22: 26, 2015.

25. Chandimali N, Sun HN, Kong LZ, Zhen X, Liu R, Kwon T and Lee DS: Shikonin-induced apoptosis of colon cancer cells is reduced by peroxiredoxin $\mathrm{V}$ expression. Anticancer Res 39: 6115-6123, 2019.

26. Ahn BZ, Baik KU, Kweon GR, Lim K and Hwang BD: Acylshikonin analogues: Synthesis and inhibition of DNA topoisomerase-I. J Med Chem 38: 1044-1047, 1995.

27. Lu Q, Liu W, Ding J, Cai J and Duan W: Shikonin derivatives: Synthesis and inhibition of human telomerase. Bioorg Med Chem Lett 12: 1375-1378, 2002. 
28. Li W, Zhang C, Ren A, Li T, Jin R, Li G, Gu X, Shi R and Zhao Y: Shikonin suppresses skin carcinogenesis via inhibiting cell proliferation. PLoS One 10: e0126459, 2015

29. Wiench B, Eichhorn T, Paulsen M and Efferth T: Shikonin directly targets mitochondria and causes mitochondrial dysfunction in cancer cells. Evid Based Complement Alternat Med 2012: $726025,2012$.

30. Wang F, Yao X, Zhang Y and Tang J: Synthesis, biological function and evaluation of Shikonin in cancer therapy. Fitoterapia 134: 329-339, 2019.

31. Andújar I, Ríos JL, Giner RM and Recio MC: Pharmacological properties of shikonin-a review of literature since 2002. Planta Med 79: 1685-1697, 2013.

32. Liang W, Cui J, Zhang K, Xi H, Cai A, Li J, Gao Y, Hu C, Liu Y, Lu Y, et al: Shikonin induces ROS-based mitochondria-mediated apoptosis in colon cancer. Oncotarget 8: 109094-109106, 2017.

33. Boulos JC, Rahama M, Hegazy MF and Efferth T: Shikonin derivatives for cancer prevention and therapy. Cancer Lett 459 : 248-267, 2019

34. Ali A, Assimopoulou AN, Papageorgiou VP and Kolodziej H: Structure/antileishmanial activity relationship study of naphthoquinones and dependency of the mode of action on the substitution patterns. Planta Med 77: 2003-2012, 2011.

35. Lee SH, Shen GN, Jung YS, Lee SJ, Chung JY, Kim HS, Xu Y, Choi Y, Lee JW, Ha NC, et al: Antitumor effect of novel small chemical inhibitors of Snail-p53 binding in K-Ras-mutated cancer cells. Oncogene 29: 4576-4587, 2010.

36. Chen X, Yang L, Oppenheim JJ and Howard MZ: Cellular pharmacology studies of shikonin derivatives. Phytother Res 16: 199-209, 2020

37. Elferink JG and Deierkauf M: Inhibition of polymorphonuclear leukocyte functions by fluorinated nitrobenzenes. Chem Biol Interact 52: 163-72, 1984.

38. Sun HN, Shen GN, Jin YZ, Jin Y, Han YH, Feng L, Liu L, Jin MH, Luo YH, Kwon TH, et al: 2-Cyclohexylamino5,8-dimethoxy-1,4-naphthoquinone inhibits LPS-induced BV2 microglial activation through MAPK/NF-kB signaling pathways. Heliyon 2: e00132, 2016.

39. Gaascht F, Teiten MH, Cerella C, Dicato M, Bagrel D and Diederich M: Plumbagin modulates leukemia cell redox status. Molecules 19: 10011-10032, 2014.

40. Zhang J, Peng S, Li X, Liu R, Han X and Fang J: Targeting thioredoxin reductase by plumbagin contributes to inducing apoptosis of HL-60 cells. Arch Biochem Biophys 619: 16-26, 2017.

41. Sharma A, Santos IO, Gaur P, Ferreira VF, Garcia CR and da Rocha DR: Addition of thiols to o-quinone methide: New 2-hydroxy-3-phenylsulfanylmethyl[1,4]naphthoquinones and their activity against the human malaria parasite Plasmodium falciparum (3D7). Eur J Med Chem 59: 48-53, 2013.

42. Pandey SK, Naware NB, Trivedi P and Saxena AK: Molecular modeling and 3D-QSAR studies in 2-aziridinyl-and 2,3-bis(aziridinyl)-1,4-naphthoquinonyl sulfonate and acylate derivatives as potential antimalarial agents. SAR QSAR Environ Res 12: 547-564, 2001.

43. Bielitza M, Belorgey D, Ehrhardt K, Johann L, Lanfranchi DA, Gallo V, Schwarzer E, Mohring F, Jortzik E, Williams DL, et al: Antimalarial NADPH-consuming redox-cyclers as superior glucose-6-phosphate dehydrogenase deficiency copycats. Antioxid Redox Signal 22: 1337-1351, 2015.
44. Edenharder R and Grünhage D: Free radical scavenging abilities of flavonoids as mechanism of protection against mutagenicity induced by tert-butyl hydroperoxide or cumene hydroperoxide in Salmonella typhimurium TA102. Mutat Res 540: 1-18, 2003.

45. Fukushi S, Yoshino H, Yoshizawa A and Kashiwakura I p53-independent structure-activity relationships of 3-ring mesogenic compounds' activity as cytotoxic effects against human non-small cell lung cancer lines. BMC Cancer 16: 521, 2006.

46. Gao M, Wang R, Yu F and Chen L: Evaluation of sulfane sulfur bioeffects via a mitochondria-targeting selenium-containing near-infrared fluorescent probe. Biomaterials 160: 1-14, 2018.

47. Santarpia L, Lippman SM and El-Naggar AK: Targeting the MAPK-RAS-RAF signaling pathway in cancer therapy. Expert Opin Ther Targets 16: 103-119, 2012.

48. Zhu J, Blenis J and Yuan J: Activation of PI3K/Akt and MAPK pathways regulates Myc-mediated transcription by phosphorylating and promoting the degradation of Mad1. Proc Natl Acad Sci USA 105: 6584-6589, 2008.

49. Steelman LS, Chappell WH, Abrams SL, Kempf RC, Long J, Laidler P, Mijatovic S, Maksimovic-Ivanic D, Stivala F, Mazzarino MC, et al: Roles of the Raf/MEK/ERK and $\mathrm{PI} 3 \mathrm{~K} / \mathrm{PTEN} / \mathrm{Akt} / \mathrm{mTOR}$ pathways in controlling growth and sensitivity to therapy-implications for cancer and aging. Aging (Albany NY) 3: 192-222, 2011.

50. Asati V, Mahapatra DK and Bharti SK: PI3K/Akt/mTOR and Ras/Raf/MEK/ERK signaling pathways inhibitors as anticancer agents: Structural and pharmacological perspectives. Eur J Med Chem 109: 314-341, 2016.

51. Romashkova JA and Makarov SS: NF-kappaB is a target of AKT in anti-apoptotic PDGF signalling. Nature 401: 86-90, 1999.

52. Gingery A, Bradley EW, Pederson L, Ruan M, Horwood NJ and Oursler MJ: TGF-beta coordinately activates TAK1/MEK/AKT/NFkB and SMAD pathways to promote osteoclast survival. Exp Cell Res 314: 2725-2738, 2008.

53. Delire B and Stärkel P: The Ras/MAPK pathway and hepatocarcinoma: Pathogenesis and therapeutic implications. Eur J Clin Invest 45: 609-63, 2015.

54. Rommel C, Clarke BA, Zimmermann S, Nuñez L, Rossman R, Reid K, Moelling K, Yancopoulos GD and Glass DJ: Differentiation stage-specific inhibition of the Raf-MEK-ERK pathway by Akt. Science 286: 1738-1741, 1999.

55. Balmanno K, Chell SD, Gillings AS, Hayat S and Cook SJ: Intrinsic resistance to the MEK1/2 inhibitor AZD6244 (ARRY-142886) is associated with weak ERK1/2 signalling and/or strong PI3K signalling in colorectal cancer cell lines. Int J Cancer 125: 2332-2341, 2009.

56. Gholampour M, Ranjbar S, Edraki N, Mohabbati M, Firuzi O and Khoshneviszadeh M: Click chemistry-assisted synthesis of novel aminonaphthoquinone-1,2,3-triazole hybrids and investigation of their cytotoxicity and cancer cell cycle alterations. Bioorg Chem 88: 102967, 2019.

This work is licensed under a Creative Common Attribution-NonCommercial-NoDerivatives 4.0 International (CC BY-NC-ND 4.0) License. 